\title{
生涯教育の担い手としての総合内科專門医 セルフトレーニング問題を中心に
}

岡崎 仁昭

Key words : 生涯学習, セルフトレーニング問題

〔日内会誌 97 : 1922～1929，2008〕

はじめに

現在, 多くの総合内科専門医が本会の生涯教 育事業に関わっている. 第一に資格認定試験(認 定内科医・総合内科専門医）への貢献が挙げら れる. 問題作成, 病歴要約の評価, 試験監督な どに総合内科専門医が関わっている. 特に病歴 要約の評価はほとんど総合内科専門医が担当し ており, 平成 19 年度は約 300 名の総合内科専門 医によって行われた. 認定内科医の 1 人当りの 病歴要約は内科 9 分野の 9 症例を含めて計 18 症例であり, 各評価委員は受験者 10 名程度 (計 180 症例)の病歴要約を査読し, 採点している. 第二に教育セミナーの開催が挙げられる. 各支 部での教育セミナーが年 1〜2 回開催されており, 平成 20 年度は 9 支部において計 17 回開催され る予定である。

筆者はこれまでに本会の生涯教育事業の中で, 上記の資格認定試験やセルフトレーニング問題 作成の世話人として関わってきた，本稿では試 験問題の在り方, その作成方法の紹介および今 後の取り組みについて述べたい. 現在, セルフ トレーニング問題の作成は全員, 総合内科専門 医によって行われている. 受験者も毎年, 増加 しており参加型生涯学習法の 1 つとして, その

おかざき ひとあき：自治医科大学内科学講座アレル ギー膠原病学部門
役割がますます重要になっている.

なお, 医学全般における生涯教育の重要性に ついては既に本学会誌で取り上げられているの で，そちらを参考にしていただきたい1).

大学病院に勤務している総合内科専門医であ れば, 学生教育の評価法としての試験問題, 特 に多肢選択式問題の作成に携わっていると思わ れる.筆者が勤務する大学では, CBT<computer based test $>の$ 作成や医師国家試験の対策のため, 学内の試験問題の多くで多肢選択式問題が使用 されている. 多肢選択式問題の最大の特徵は評 価の客観性である。論文式記述試験, 口述試験 あるいはOSCE< objective structured clinical examination >が多少なりとも評価者の主観が入 らざるを得ないのに比較すると多肢選択式問題 の客観性は著しく高い. 採点が機械的に行える ことと併せて, 受験者の多い資格認定試験やセ ルフトレーニング問題には適している22.

\section{セルフトレーニング問題受験者の推移}

平成 10 年度から認定内科医・総合内科専門医 の認定更新のための新たな単位取得方法として, セルフトレーニング問題が加えられた。 また平 成 15 年度から総合内科専門医は更新期間内（5 年）に 1 回セルフトレーニングの問題を受ける ことが義務化されたことにより, 年々受験者は 増加している (表). 
表 . セルフトレーニング問題受験者の推移

\begin{tabular}{|c|c|c|c|}
\hline 年度 & 受験者 & 平均正解率 & 60\% 以上で単位取得者（\%) \\
\hline 平成 10年 & 1 ,284 名 & 73.3\% & 1,088 名（84.7\%） \\
\hline 平成 11 年 & 1,175名 & $72.4 \%$ & 1,008 名 (85.4\%) \\
\hline 平成 12年 & 1,137名 & $70.5 \%$ & 938 名（82.5\%） \\
\hline 平成 13 年 & 845 名 & $74.4 \%$ & 771 名 (91.2\%) \\
\hline 平成 14年 & 932 名 & $77.3 \%$ & 891 名 (95.6\%) \\
\hline 平成 15年 & 2.994 名 & $81.6 \%$ & 2.914 名（97.3\%） \\
\hline 平成 16 年 & 3,484 名 & $82.5 \%$ & 3,409 名 (97.8\%) \\
\hline 平成 17年 & 4,030 名 & $81.5 \%$ & 3.913 名（97.1\%） \\
\hline 平成 18年 & 4,829 名 & $74.9 \%$ & 4,504 名（93.2\%） \\
\hline 平成 19年 & 5,965 名 & $77.7 \%$ & 5.765 名（97.2\%） \\
\hline
\end{tabular}

平成 10 年〜 14 年までは受験が義務化されてい なかったこともあり, 参加者は 1,000 名前後であっ た. 総合内科専門医に義務化された平成 15 年以 降は表に示すように増加し, 平成 19 年度は約 6,000 名が受験した. 平成 20 年度の医師国家試験受験 者数は 8,500 名程度であったが, 各種専門医試験 受験者数と比較して, セルフトレーニング問題 は医師国家試験に次ぐ受験者数を示す大規模な 試験となった.

\section{資格認定試験問題の在り方に関する小委員 会}

平成 16 年, 旧内科専門医会時代に上記の小委 員会が立ち上げられた（委員：岡崎仁昭, 早野 恵子, 白浜雅司). そのきっかけは当時, 資格認 定試験の試験監督を担当していた複数の総合内 科専門医から以下のような意見が出されたから である。

○受験者の多くが, 医学生が医師国家試験対 策用で有名な対策本を使用していた。問題が知 識偏重の, 単なる細切れの知識を想起させる夕 クソノミーI型（マニュアルの項を参照）が多い ため, 対策本で解答できてしまう.

○特に総合内科専門医試験では, 各専門分野 での専門医試験で出題されるような難問が目立っ た.

\section{当時の小委員会の意見として}

(1)知識偏重になりがちな現在の形式の見直し が必要である.例えば教科書持込みの試験＜openbook examination>などの方法も考えられる.

(2)各専門分野の作成を専門家でない総合内科 専門医に委託して作成すると改善される可能性 がある。

(3)悪問を抽出して検証する.

(4)作成者のためにマニュアルを作成し，作成 者自身のトレーニングを企画する.

(5)資格認定試験で実践する前に, セルフトレー ニング問題で上記試みを実践する.が出された.

(1)現在のセルフトレーニング問題はopen-book examinationであり, まずはセルフトレーニング 問題から改善していくことになった. タクソノ ミーI型よりはIII型形式の問題解決型 $<$ problem solving $>$, 臨床現場での臨床判断を問うような ものに改善していく. 具体的にはcommon disease で, 重大な結果を招く疾患（緊急性, 致死的, killer disease), 治療可能な疾患, 見逃しやすい 疾患などを主に出題する。問題形式が変わるこ とで, 受験者はいわゆる対策本では対応できな くなり, 標準的な教科書を読むようになること が期待される.

(2)については総合内科専門医の役割は大きく, 内科全体を見渡せる能力が必要である.

(3)(4)ついては, 筆者が中心となりマニュア 
ルを作成した.

さらに問題のことは受験者に尋ねるのが良い との指摘から, セルフトレーニング問題受験後 のアンケートを施行した.

\section{セルフトレーニング問題の作成}

セルフトレーニング問題は認定内科医・総合 内科専門医の生涯教育の一環として, 臨床レベ ルを維持するために必要な知識を勉強して貫う ためのものである. そのため出題する問題は, 日常臨床に必要な診断, 治療の実際的な知識を 問う問題に絞ることにした.すなわちまれな疾 患は避けて, 検查や治療もあまり専門的なもの は入れないように工夫した。またトピックス的 なものとしては最近保険適応になって是非知っ ておくべき治療法などを取り上げるように改善 した.コンセプトとしては，明日からの診療に 役立つ問題作成を目指した。問題作成者には, マニュアルを用意し，それに沿って作成してい ただいた．問題は作成者による問題検討委員会 と審議会専門委員によるブラッシュアップを経 て修正され，問題の表現・語句，難易度，均質 性なども十分に配慮され, 出題された. 以下に 問題作成マニュアルの一部を記載する。これは CBTや医師国家試験問題の作成上の留意点を参 考に，改変したものである.

1 セルフトレーニング問題作成の留意点

（1）多肢選択式問題の採点は, 機械的に行わ れるので, 作題には十分な時間をかけて吟味し, 細心の注意が久かせない.

（2） 50 題の多肢選択式問題は, 均質な問題群 としてまとめられるので, 範囲, 難易度, 形式, 語句などは共通の約束の枠内で作られることが 望ましい.「これでも良いはず」という枠はずれ は, 修正が必要となる. 対象は学会などに積極 的に参加している会員ではなく, 主として開業 医や病院勤務医であるので，あまり専門的な内 容は含めるべきではない. 日常臨床に必要な診
断，治療の実際的な知識を問う問題で，トピッ クス的なものでも保険適応になっているか, も しくは日本内科学会雑誌で解説され, その価值 が認められている検査や治療からの出題が望ま しい.

（3）臨床現場での臨床判断を問うような出題 が望ましい.

(4) 簡潔で日本語としてのあいまいさを残さ ない明暸な文章とする．不特定多数の受験者の 誰が読んでも, 誤解を招かない多義性のない文 章とする。新聞などで使われる標準語で記し, カルテ用語や学会発表用語は避ける.

\section{2 多肢選択問題の分類}

1）形式による分類

A型：単純択一形式 (One-Best-Response) 1 つ選べ.

a b c d e

2) Taxonomy（問いの深さ）による分類

I (想起)：基本的知識の有無を問う問題

II（分析・解釈）：基本的知識に基づいて分析, 統合, 解釈する力を問う問題

III（応用・問題解決）：基本的知識を応用し, 問題解決をする力を問う問題

臨床実地問題ではIIかIIIが望ましい.

3 セルフトレーニング問題作成の一般的留意 事項

1）出題範囲は日本内科学会認定医研修カリ キュラムに準拠する.

2）問題形式はすべてA型とする.

3）特に注意すべき表現について

○人名は原語によること(例：Down症候群).

○薬品は「〜薬」という記載にし, 日本医薬 品集（赤本）に準拠する.

○必ず」,「常に」,「すべて」などの限定語は 使わない.

○設問が否定形の場合は，選択肢を否定形に しない（二重否定を避ける）.

○原則的に選択肢はすべて対等の重みを持ち, 同一範疇の事象にまとめる. 
○各選択肢はできるだけ名詞一語にした方が 良問になりやすい.

$\bigcirc 1$ つの選択肢に 2 つ以上の内容を含ませない. ○各選択肢の長さは大体等しくする.

○選択肢の配列に留意し，できるだけ論理的 順序とする。

例えば，解剖学的高位から低位， ABC順, 短〜長文順に統一する.

\section{a \\ b $\bigcirc \bigcirc \bigcirc$ \\ c $\bigcirc 000$ \\ d 00000 \\ e 000000 \\ 4 問題の構成（一般問題の例） \\ 作成例}

まず出題する疾患を決める.

Step 1 例えば, 抗リン脂質抗体症候群を出題 することにする.

Step 2 次に抗リン脂質抗体症候群が日本内科 学会認定医研修カリキュラムに含まれることを 確認する.

Step 3 今回は抗リン脂質抗体症候群の臨床症 状を問う出題とする.

Step 4 選択肢は文章ではなく, 名詞一語に配 列する.

設問文：抗リン脂質抗体症候群を疑わせる症 候はどれか. 1 つ選べ.

選択肢：選択肢の配列は各選択肢が独立した 症候であるので，短〜長い順に配列した。
a 発 熱
b 関節炎
c 蝶形紅斑
d 習慣流産
e リンパ節腫脹

Step 5 問う内容を症候ではなく, translational な知識を問う選択肢に訂正し，最終的にブラッ シュアップされた問題を以下に示す.

抗リン脂質抗体症候群を疑わせる妊娠合併症 はどれか. 1 つ選べ.
a 前期破水
b 前置胎盤
c 習慣流産
d 子宮外妊娠
e 羊水過多症
正解 : c

セルフトレーニング問題受験者に対するア ンケート調査

平成 16 年, 旧内科専門医会時代に認定医試験 問題の在り方に関する小委員会からの答申を受 けて, 平成 17 年度のセルフトレーニング問題受 験者に対して，以下のアンケート調査が施行さ れた(アンケート作成は早野恵子先生による)。

1. 先生の背景についてお尋ねします.

(1)いずれかに○をつけて下さい.

（）認定内科医，（）認定内科専門医 (2)卒後（）年目（）男性,（）女 性

(3)勤務先は?

（）開業医または診療所

（）勤務医(私立病院, 公的病院, 大学病 院）

（）その他（）

2. 全体的に見て, 2005 年度のセルフトレーニ ング問題の内容についてはどのように思われま したか?

1. 非常に良かった

2. やや良かった

3. どちらでもない

4. やや悪かった

5. 非常に悪かった

3. セルフトレーニング問題の内容で良かった 点を具体的にお書き下さい.

4. 七ルフトレーニング問題の内容で悪かった 点や改善すべき点を具体的にお書き下さい.

5. セルフトレーニング問題の出題について現 在不足していると思われる領域は？ 
）(1)知識（想起）

) (2)技術

) (3)態度

）(4)思考過程

) (5)問題解決

) (6)臨床倫理

) (7)その他

6. セルフトレーニング問題の設問や方法につ いてはどのように思われますか？

（）1. 現在の形式で良い. (多肢選択形式)

）2. 試験の形式を変えてほしい.

）3.わからない.

2.に○をつけた方は, 具体的にどのような 形式を望みますか?

7. セルフトレーニング問題の設問数はいかが ですか？

（）1. 現行の通りでよい.（多肢選択形式 50 問)

）2.もっと増やしてほしい.

）3. もっと減らしてほしい.

8. セルフトレーニング問題の設問の難易度は いかがですか？

）1. 現行の通りでよい.

）2. もっと難易度を上げてほしい.

）3. もっと難易度を下げてほしい。

9. 単位の取得に関してはどのように思われま すか?

（）1. 現行の通りでよい.

(全問の正解率 $60 \%$ 以上のものに対して認定 更新研修単位 5 単位取得)
）2. もっと増やしてほしい.
） 3. もっと減らしてほしい.
) 4. その他 (

10. セルフトレーニング問題集に関して，ご 要望・ご提案がありましたら，ご自由にお書き 下さい.

主な結果を図 1〜9(図 1：本会の資格, 図 2： 卒後年数, 図 $3:$ 性別, 図 $4:$ 勤務先, 図 $5:$ 問 題の内容, 図 6 : 設問数, 図 7 : 問題の難易度,

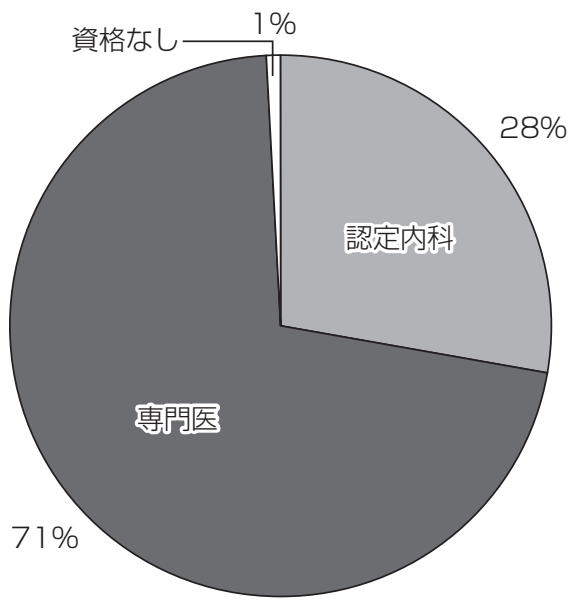

図 1. 本会資格

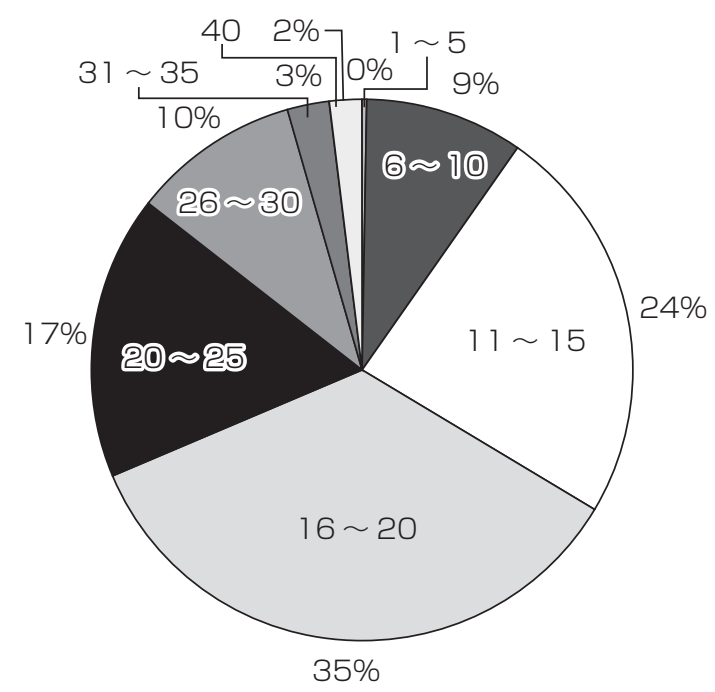

図 2. 卒後年数

図 8：取得単位数, 図 9: 問題の不足領域)に示 す.アンケート回答者は 374 名で回答率は $7.8 \%$ であった. 受験者の内訳は約 70\% が総合内科専 門医で卒後 11〜20 年目で約半数を占めた. 大学 病院に勤務している者は全体の約 4 分の 1 に過 ぎず，診療所や一般病院に勤務している受験者 が多数を占めていた. 問題の内容については約 $70 \%$ の受験者が非常に良い〜やや良いとの評価 を下していた。設問数や難易度についても現状 


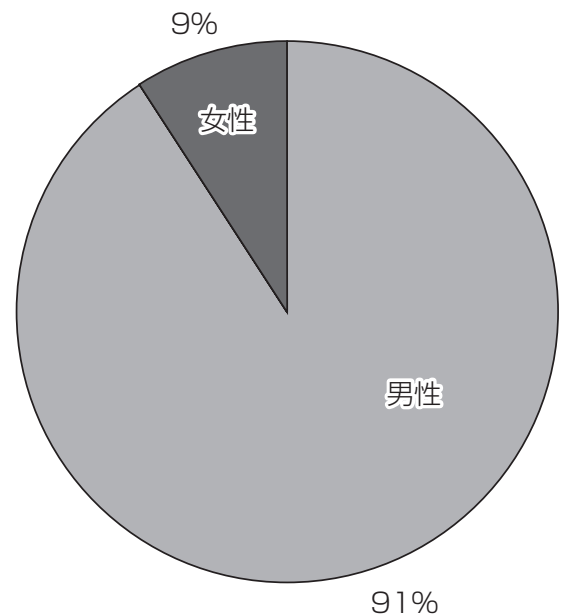

図 3. 性別

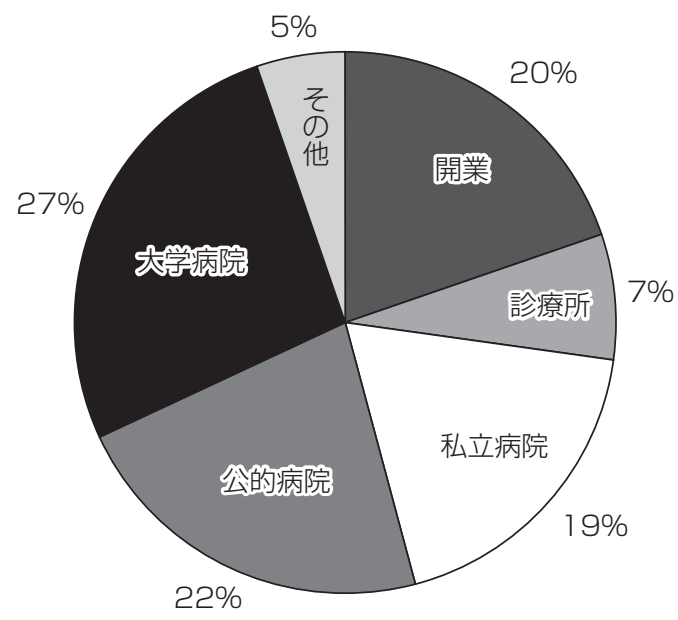

図 4. 勤務先

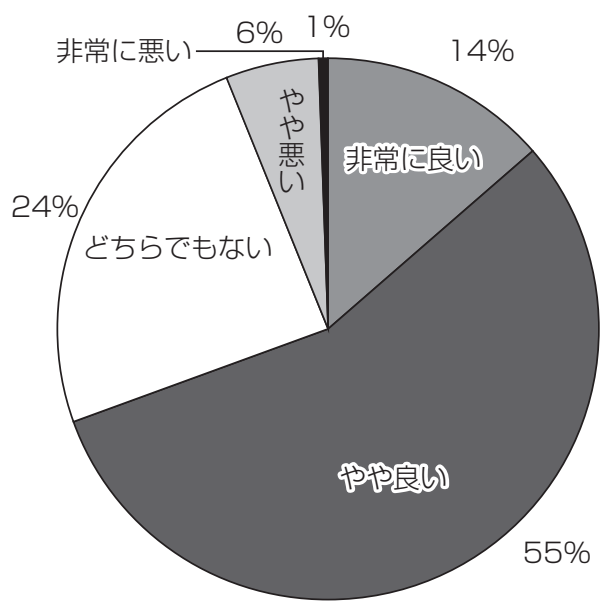

図 5. 問題の内容

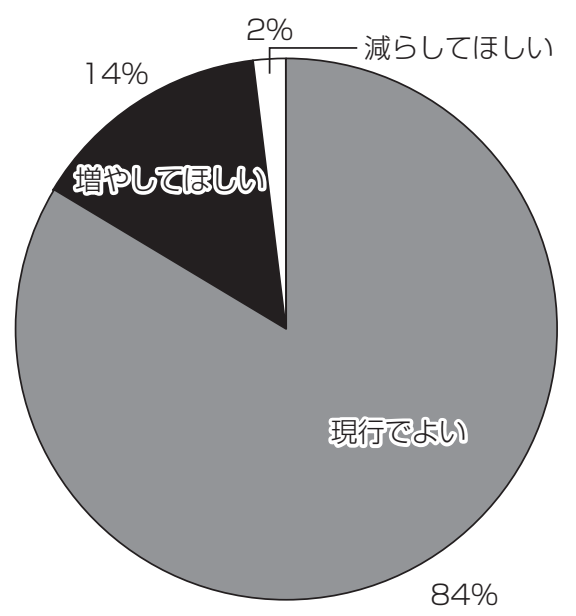

図 6. 設問数
のレベルが妥当と考える受験者が多かった。一 方で不足領域としては思考過程, 問題解決型お よび臨床倫理に関する出題が挙げられた。また 取得単位数については, 現行では $60 \%$ 以上の正 解率の者に 5 単位であるが, その増加を望む声 もあった. その他の要望, 良かった点, 悪かっ た点・改善すべき点で指摘された主な意見を列 挙する.

\section{要望・意見}

○年 $2 \sim 3$ 回施行してほしい.

○インターネット上でオンラインにて解答で きるようにしてほしい.

○認定内科医にも義務化すべきである.

○講演会とは異なり, 自ら学ぶことができる 生涯教育の方法だと思う。

良かった点

○難問，奇問が減った。 


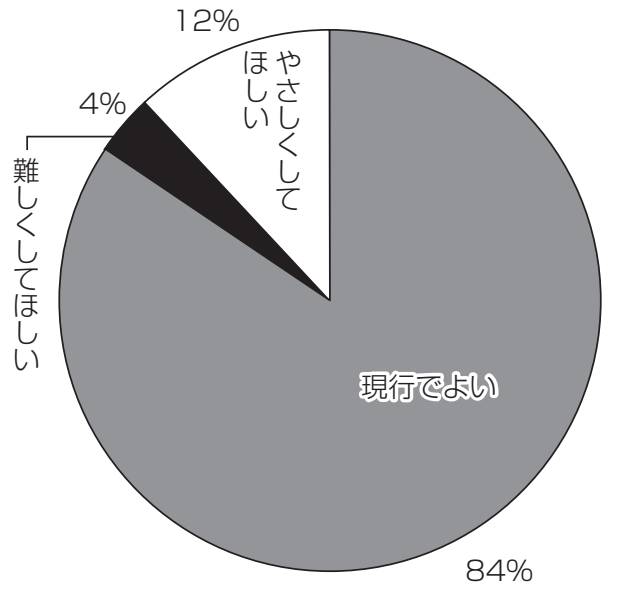

図 7. 問題の難易度

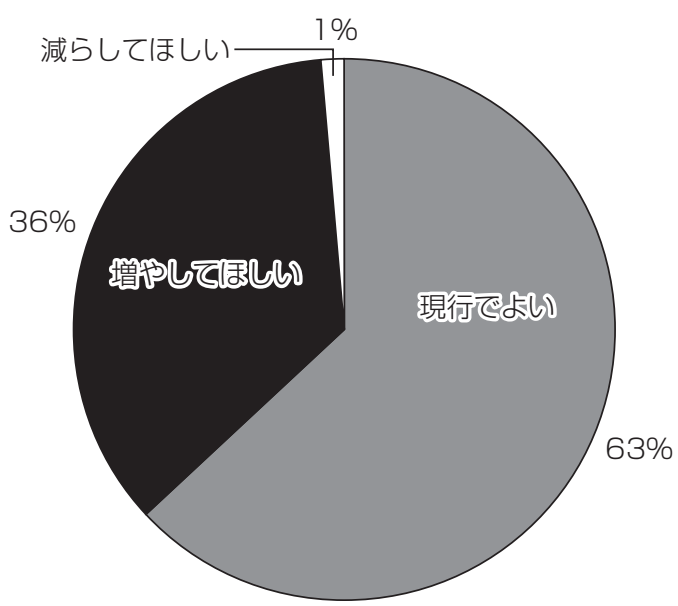

図 8. 取得単位数

○最新の内容が含まれていた.

○災害医療 (トリアージ), 心肺蘇生法, 感染 症（ノロウイルス）が勉強になった.

○医師としての判断を問う問題が良かった.

○評価の高かった問題の例

61 歳の女性. 毎年の健康診断で異常はなかっ たが，今年の人間ドックでリウマトイド因子陽 性を指摘されたため来院した，ときどき両手指 関節痛を自覚していたが, 日常生活に支障はな く，朝のこわばりもない.

身体所見：心肺, 腹部に異常はない. 両側遠

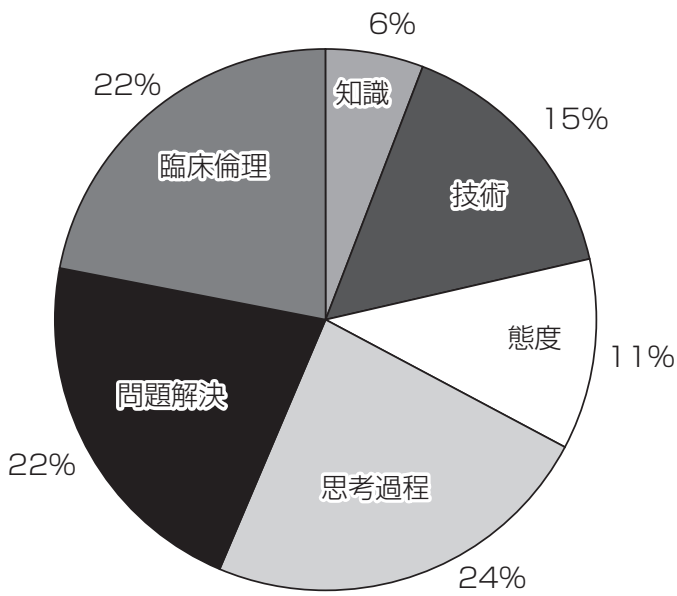

図 9. 問題の不足領域

位指節間関節の結節状腫大と変形とがみられる が，運動時痛はない，他の関節に疼痛，腫脹お よび発赤はない.

検査所見：血液所見; 白血球 $6,100 / \mu 1$. 血液生 化学所見 ; 総蛋白 $7.6 \mathrm{~g} / \mathrm{dl}$, アルブミン $4.0 \mathrm{~g} / \mathrm{dl}$, 尿素窒素 $16 \mathrm{mg} / \mathrm{dl}$, クレアチニン $0.7 \mathrm{mg} / \mathrm{dl}$, 総 ビリルビン $0.8 \mathrm{mg} / \mathrm{dl}$, AST $25 \mathrm{IU} / \mathrm{L}, \quad$ ALT 20 IU/L，ALP 105 IU/L（基準 89〜285)，CRP 0.05 $\mathrm{mg} / \mathrm{dl}, \mathrm{RF} 40 \mathrm{IU} / \mathrm{ml}$ (基準 20 未満), 抗核抗体 陰性, CH50 $30.5 \mathrm{U} / \mathrm{ml}$ （基準 24.7〜39.5）.

この時点で最も適切な対応はどれか. 1 つ選べ.
a 経過観察
b 非ステロイド性抗炎症薬投与
c 抗リウマチ薬投与
d 副腎皮質ステロイド薬投与
e 生物学的製剂投与
正解 : a

\section{悪かった点, 改善すべき点}

○画像写真が不鮮明であった.

○知識を問う問題が多かった.

○難易度に差が大きい。

○医療面接や身体診察に関する問題を増やす 
ベきである.

○がん関連の出題が少な過ぎる.

○漢方医学領域からも出題してはどうか.

アンケートの結果からは, 全体としては, 現 行の問題に満足している受験者が多いことが判っ た、しかし，未だに改善すべき点があるのは事 実であり，これらの意見をできる限り反映させ ていくべきである。まずは会員の利便性からイ ンターネット上でのオンライン化は実現可能で あろう。なお，資格認定試験の在り方について は, 現在, 認定医制度審議会において活発に議 論されている.

\section{最後に}

生涯教育担当者としての総合内科専門医の活 動を本稿ではセルフトレーニング問題に焦点を 合わせて紹介した，受験者が生涯学習の 1 つと して受け入れ充実感を覚えるような後味の良い 問題の作成は難しいが，質の良い医療のために は必要であると思われる。

ごく最近, 過去 5 年分のセルフトレーニング
問題をさらにブラッシュアップし, 解説の部分 も新しいガイドラインに即するなどの修正を行 い, 単行本として出版する運びとなった ${ }^{3)}$. 本書 が会員の皆様の生涯教育の一助として, 少しで もお役に立てば幸いである。また問題に関する 参加型の生涯学習法としては, セルフトレーニ ング問題の他に, CME次世代教育システムのコ ンテンツが本会のホームページから閲覧可能で ある.コンテンツ作成には多くの総合内科専門 医が関わっている. 是非, こちらも御利用いた だきたい。

謝辞 本稿の一部は, 旧内科専門医会の資格認定試験問題 の在り方に関する小委員会のメンバーであった早野恵子先生, 白浜雅司先生と議論したものである. またセルフトレーニン グ問題作成には多くの総合内科専門医の先生方に御協力いた だいている。ここに記して深甚の謝意を表します.

\section{文献}

1）北村 聖, 永井良三 : 生涯教育 : わが国の現状. 日内会 誌 $96: 94-100,2007$.

2) 齋藤寿一: 多肢選択式問題のその作り方. 内科臨床研修 指導マニュアル. 日本内科学会認定内科専門医会編. 東 京, 2001, 44-49.

3）生涯教育のためのセルフトレーニング問題と解説. 日本 内科学会専門医部会編, 東京, 2008 . 